\title{
PERAN WORD OF MOUTH MEMEDIASI PENGARUH KEPUASAN TERHADAP LOYALITAS KONSUMEN PADA GREEN PRODUCT MEREK ORIFLAME DI KOTA DENPASAR
}

\author{
Ni Nyoman Adityarini Abiyoga Vena Swara ${ }^{(1)}$ \\ Ni Made Kansa Dewi Putri ${ }^{(2)}$ \\ ${ }^{(1)}$ Fakultas Ekonomi, Universitas Hindu Indonesia, Denpasar, Bali \\ (2)Sekolah Tinggi Manajemen Informatika, STIKOM, Bali \\ email: adityarini92@gmail.com
}

\begin{abstract}
ABSTRAK
Increased human awareness of the importance of preserving natural resources has made many producers of various types of products begin to switch to using materials that do not damage the environment or known as green products. This change in the concept of marketing based on the environment requires the right marketing strategy to create customer satisfaction and loyalty. Retained customers will be happy to express positive things and provide recommendations about products to others (Word of Mouth). This research was conducted on consumers in the city of Denpasar by using data from the number of Oriflame consultants as many as 100 people. Data were analyzed by path analysis techniques, where the validity and reliability tests were carried out in the initial stages of testing. The results of the analysis show that satisfaction and word of mouth have a significant effect on consumer loyalty on the Oriflame brand green product. Word of Mouth also plays a role in mediating the effect of satisfaction on consumer loyalty on the Oriflame brand green product. For this reason, to encourage positive word of mouth from consumers, the combination of product quality and good service quality will encourage customer satisfaction which ultimately leads to an increase in customer loyalty.
\end{abstract}

Keywords: satisfaction, word of mouth, loyalty, green product

\section{PENDAHULUAN}

Perubahan paradigma atau konsep pemasaran berbasis lingkungan yang saat ini sedang berkembang ditengah semakin kritisnya konsumen, mendorong perusahaan untuk merancang strategi pemasaran yang tepat. Penggunaan istilah "Back to Nature" pada beberapa produk, salah satunya dalam industri kosmetik banyak digunakan untuk mendorong keputusan pembelian konsumen pada produk 
tersebut. Green consumer merupakan segmen khusus bagi pemasar, dimana semakin banyak konsumen yang mengganti produk konsumsinya dengan produk ramah lingkungan bahkan konsumen bersedia membayar lebih untuk green product (Khoiriyah \& Suam Toro, 2014). Fenomena ini memberikan peluang kepada perusahaan untuk meningkatkan kinerja produknya yang ramah lingkungan untuk memperkuat ekuitas mereknya.

Kekuatan sebuah perusahaan untuk membangun ekuitas mereknya bersumber dari sejauh mana perusahaan mampu untuk meningkatkan sekaligus mempertahankan kepuasan konsumen. Terciptanya kepuasan konsumen dapat memberikan manfaat, diantaranya hubungan antara perusahaan dan konsumen menjadi kuat, memberikan kesan yang baik bagi konsumen, membentuk suatu rekomendasi dari konsumen yang satu ke konsumen yang lain yang dapat menguntungkan perusahaan dan terciptanya loyalitas konsumen.

Beberapa penelitian telah dilakukan terkait dengan pengaruh kepuasan terhadap loyalitas konsumen pada green product. Penelitian oleh Chang dan Fong (2010) menyatakan bahwa kepuasan terhadap green product didefinisikan sebagai pelanggan yang merasa dengan mengkonsumsi produk ramah lingkungan untuk memenuhi kebutuhan, keinginan, dan tujuannya mengenai masalah lingkungan dan pemenuhan ini adalah hal yang menyenangkan. Penelitian lainnya juga menyatakan bahwa loyalitas pelanggan terhadap produk hijau merupakan tingkat dimana pelanggan berkomitmen untuk melakukan pembelian berulang, merekomendasikan produk hijau, dan memiliki sikap positif terhadap produk ramah lingkungan tersebut (Susanti dan Wardana, 2015). Sementara penelitian 
oleh Hayu (2014) menyatakan bahwa kepuasan tidak berpengaruh signifikan terhadap loyalitas konsumen pada green product. Penelitian ini dilakukan pada Komunitas Kandang Village di Kota Bengkulu yang menggunakan produk penerangan hemat energi. Konsumen yang puas akan nilai produk dan merek dari produsen, cenderung akan merekomendasikan produk tersebut kepada konsumen lainnya. Selayaknya virus yang dapat melakukan penyebaran dengan sangat cepat yang semula hanya diawali oleh satu orang yang memiliki jaringan luas, dapat memberikan pengaruh terhadap pemasaran perusahaan. Melihat kekuatan pengaruh pemasaran "dari mulut ke mulut" tersebut, produsen sebuah produk perlu untuk focus dalam menjalankan Word of Mouth. Membuat pelanggan membicarakan (do the talking), mempromosikan (do the promotion), dan menjual (do the selling).

Mempertahankan loyalitas konsumen juga menjadi perhatian utama dari PT. Orindo Alam Ayu sebagai distributor resmi produk merek Oriflame di Indonesia. Oriflame yang berbasis di Swedia, saat ini telah beroperasi di lebih dari 60 negara di seluruh dunia. Konsistensi Oriflame dalam memasarkan produk kosmetik ramah lingkungan dengan menggunakan bahan dasar alami atau natural serta inovasi teknologi terkini membuat produk Oriflame menjadi salah satu produk kosmetika yang terkenal di seluruh dunia. Dipasarkan oleh hamper 3,6 juta konsultan independen Oriflame, dimana telah mencapai penjualan tahunan melebihi $€ 1.5$ miliar di seluruh dunia.

Oriflame sendiri secara konsisten menawarkan keunggulan produk berbasis lingkungan, dengan label alami atau natural pada setiap produk yang 
ditawarkannya. Komitmen untuk konsisten menawarkan produk berkonsep hijau atau "Back to Nature" tersebut menjadi kunci sukses bagi Oriflame untuk memenangkan persaingan pada industri kosmetik di Indonesia khususnya. Disamping terus berupaya mengembangkan program - program peningkatan loyalitas konsumen melalui program berbasis pelanggan.

Berdasarkan hasil riset Kementerian Perindustrian Tahun 2016 pada industri kosmetik di Indonesia, menunjukkan bahwa pada tahun 2016 penjualan kosmetik dalam negeri sebesar 36 triliun, meningkat lebih dari dua kali lipatnya dibandingkan tahun 2015 yang sebesar 14 triliun. Dimana Oriflame sendiri menempati posisi ketujuh dengan pangsa pasar sebesar 3,6 persen, dimana pangsa pasar tersebut masih jauh dibawah merek kosmetik lokal seperti Wardah $(37,8$ persen), Pixy (10,1 persen), dan Sari Ayu (8,7 persen). Melihat semakin ketatnya persaingan dalam industri kosmetik di Indonesia, perusahaan perlu terus mengembangkan strategi pemasaran untuk meningkatkan loyalitas konsumen, tentunya dengan menganalisis terlebih dahulu bagaimana kekuatan word of mouth sebagai salah satu bentuk komunikasi berbasis pelanggan dalam memediasi pengaruh kepuasan terhadap loyalitas konsumen.

Berdasarkan fenomena yang telah dipaparkan maka peneliti perlu melakukan penelitian terkait pengaruh kepuasan, word of mouth, dan loyalitas konsumen pada green product merek Oriflame di Kota Denpasar. Adapun tujuan penelitian ini adalah: 1) Untuk mengetahui pengaruh kepuasan terhadap word of mouth pada green product merek Oriflame, 2) Untuk mengetahui pengaruh word of mouth terhadap loyalitas konsumen pada green product merek Oriflame, 3) 
Untuk mengetahui pengaruh kepuasan terhadap loyalitas konsumen pada green product merek Oriflame, 3) Untuk mengetahui peran word of mouth memediasi pengaruh kepuasan terhadap loyalitas konsumen pada green product merek Oriflame.

Terdapat sejumlah kajian teoritik yang digunakan yang relevan dengan variabel yang dibahas dalam penelitian ini, sebagai berikut:

\section{Green Product}

Produk hijau adalah produk yang tidak berbahaya bagi manusia dan lingkungannya, tidak boros sumber daya, tidak menghasilkan sampah berlebihan, dan tidak melibatkan kekejaman pada binatang (Kasali dalam Balawera, 2013). Produk hijau merupakan suatu produk yang dirancang dan diproses dengan suatu cara untuk mengurangi efek-efek yang dapat mencemari lingkungan, baik dalam produksi, pendistribusian, dan pengkonsumsiannya.

\section{Loyalitas Konsumen}

Menurut Griffin (2005) menyatakan definisi loyalitas adalah sebagai berikut : "Loyalty is define as non random purchase expressed over time by somedecision making unit" dari pengertian tersebut terlihat bahwa loyalitas mengacu pada suatu perilaku yang ditunjukkan dengan pembelian rutin yang didasarkan pada unit pengambilan keputusan. Oliver dikutip dalam Gaffar (2007) mengemukakan bahwa loyalitas konsumen (pelanggan) adalah : "Komitmen konsumen bertahan secara mendalam untuk berlangganan kembali atau melakukan pembelian ulang produk atau jasa terpilih secara konsisten dimasa 
yang akan datang, meskipun pengaruh situasi dan usaha-usaha pemasaran mempunyai potensi untuk menyebabkan perubahan perilaku".

\section{Kepuasan Konsumen}

Kepuasan konsumen adalah sejauh mana manfaat sebuah produk dirasakan (perceived) sesuai dengan apa yang diharapkan pelanggan (Amir, 2005). Menurut Kotler dan Keller (2009), "kepuasan adalah perasaan senang atau kecewa seseorang yang muncul setelah membandingkan kinerja (hasil) produk yang dipikirkan terhadap kinerja (atau hasil ) yang diharapkan”. Kepuasan konsumen merupakan tingkat perasaan seseorang setelah membandingkan antara kinerja produk yang ia rasakan dengan harapannya.

\section{Word of Mouth (WOM)}

Pengetahuan konsumen atas berbagai macam merek produk lebih banyak disebabkan adanya komunikasi dari mulut ke mulut (Sutrisna \& Pawitra, 2011). Komunikasi WOM terjadi ketika konsumen memberikan saran atau pendapat dan berbagi pengalaman kepada konsumen lain tentang sebuah produk, jasa, atau merek (Schiffman \& Kanuk, 2010). Berdasarkan hal tersebut, dapat dinyatakan bahwa Word of mouth mampu mempengaruhi orang lain, image, pikiran, dan keputusan mereka. Jika kekuatan dari word of mouth digunakan dengan benar, hal tersebut dapat mempromosikan produk/layanan untuk waktu yang lama.

Berdasarkan kajian teoritik dan penelitian sebelumnya yang dijadikan bahan referensi dalam penelitian ini, dirumuskan hipotesis dalam penelitian ini sebagai berikut: 
H1: Diduga kepuasan berpengaruh signifikan terhadap word of mouth pada green product merek Oriflame.

H2: Diduga word of mouth berpengaruh signifikan terhadap loyalitas konsumen pada green product merek Oriflame.

H3: Diduga kepuasan berpengaruh signifikan terhadap loyalitas konsumen pada green product merek Oriflame.

H4: Diduga word of mouth memediasi pengaruh kepuasan terhadap loyalitas konsumen pada green product merek Oriflame.

Penelitian ini nantinya memberikan kontribusi bagi perumusan strategi pemasaran produk berbasis lingkungan sehingga perusahaan dalam hal ini PT. Orindo Alam Ayu sebagai distributor resmi produk Oriflame di Indonesia dapat memenangkan persaingan yang semakin ketat dan kompetitif. Selain itu, penelitian ini dapat dijadikan salah satu referensi dalam mempelajari ilmu manajemen, khususnya manajemen pemasaran yang terkait dengan perilaku konsumen dan green marketing.

\section{METODE PENELITIAN}

\section{Desain Penelitian}

Adapun kerangka berpikir dalam penelitian ini adalah sebagai berikut.

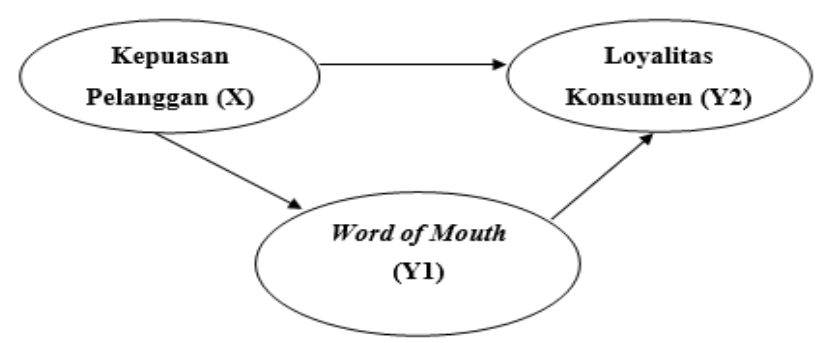

Gambar 1 Kerangka Penelitian 
Perusahaan tentunya ingin memenangkan persaingan dalam menarik konsumen secara efektif hingga menciptakan konsumen yang loyal sebagai aset utama perusahaan dalam memperoleh laba secara optimal. Kepuasan yang tercipta secara konsisten dari mengkonsumsi produk dapat menumbuhkan loyalitas konsumen. Loyalitas konsumen menjadi inti dari aktivitas dan strategi pemasaran. Konsumen yang puas cenderung merekomendasikan produk kepada konsumen lainnya, sehingga komunikasi dari mulut ke mulut atau dikenal dengan istilah word of mouth menjadi kunci sukses dalam pemasaran produk sekaligus menciptakan loyalitas konsumen pada produk tersebut.

\section{Populasi dan Sampel Penelitian}

Menurut Mustafa (2002 : 58) populasi merupakan totalitas dari semua objek atau individu yang memiliki karakteristik tertentu, jelas, dan lengkap yang akan diteliti. Populasi dalam penelitian ini adalah konsumen yang telah menjadi konsultan atau member Oriflame pada tahun 2016 dengan jumlah 348.565 orang.

Berdasarkan perhitungan dengan rumus Slovin, jumlah sampel yang mewakili populasi penelitian ini adalah sebanyak 100 orang. Metode penentuan sampel dalam penelitian ini adalah accidental sampling, yang mana merupakan teknik pengumpulan data berdasarkan kebetulan, siapa saja yang kebetulan bertemu dengan peneliti dapat digunakan sebagai sampel, bila dipandang orang tersebut cocok sebagai sumber data.

\section{Metode Pengumpulan Data}

Data yang dipergunakan dalam penelitian ini adalah data primer. Data tersebut dikumpulkan dengan wawancara langung melalui kuesioner yang 
didesain untuk memperoleh data kepuasan, word of mouth, dan loyalitas konsumen. Disamping itu, dipergunakan pula sejumlah data sekunder yang dikumpulkan melalui hasil observasi, studi dokumentasi, dan kepustakaan untuk memperkaya hasil analisis dalam penelitian ini.

\section{Teknik Analisis}

Data penelitian ini dikumpulkan dengan instrumen berupa kuesioner yang disebarkan secara langsung kepada responden. Skala yang digunakan pada penelitian ini yaitu skala Likert 5 poin. Uji validitas dan uji reliabilitas digunakan untuk meneliti apakah kuesioner yang sudah disebarkan tersebut akurat dan layak diteliti dan digunakan lebih lanjut. Penelitian ini menggunakan teknik analisis jalur (Path Analysis) untuk mengetahui pengaruh antar variabel penelitian serta Uji Sobell untuk mengetahui peran mediasi variabel word of mouth pada pengaruh kepuasan terhadap loyalitas konsumen.

\section{HASIL DAN PEMBAHASAN}

\section{Uji Validitas dan Reliabilitas}

Hasil uji validitas menunjukkan seluruh koefisien korelasi dari indikator variabel yang diuji nilainya lebih besar dari 0,30 . Hal tersebut menunjukkan bahwa seluruh indikator pada penelitian ini dinyatakan valid.

\section{Tabel 1 Uji Validitas Variabel Penelitian}

\begin{tabular}{cccc}
\hline No & Indikator & Koefisien Korelasi & Keterangan \\
\hline 1 & $\mathrm{X} 1.1$ & 0,829 & Valid \\
2 & $\mathrm{X} 1.2$ & 0,764 & Valid \\
3 & $\mathrm{X} 1.3$ & 0,792 & Valid \\
4 & $\mathrm{X} 1.4$ & 0,788 & Valid \\
5 & $\mathrm{X} 1.5$ & 0,841 & Valid \\
6 & $\mathrm{X} 1.6$ & 0,892 & Valid \\
7 & $\mathrm{X} 1.7$ & 0,852 & Valid \\
\hline
\end{tabular}




\begin{tabular}{|c|c|c|c|}
\hline 8 & X1.8 & 0,936 & Valid \\
\hline 9 & X1.9 & 0,748 & Valid \\
\hline 10 & X1.10 & 0,767 & Valid \\
\hline 11 & X1.11 & 0,654 & Valid \\
\hline 12 & X1.12 & 0.802 & Valid \\
\hline 13 & X1.13 & 0,853 & Valid \\
\hline 14 & X1.14 & 0,852 & Valid \\
\hline 15 & $\mathrm{X} 1.15$ & 0,894 & Valid \\
\hline 16 & X1.16 & 0,885 & Valid \\
\hline 17 & X1.17 & 0,896 & Valid \\
\hline 18 & Y1.1 & 0,820 & Valid \\
\hline 19 & Y1.2 & 0,763 & Valid \\
\hline 20 & Y1.3 & 0,784 & Valid \\
\hline 21 & Y1.4 & 0,756 & Valid \\
\hline 22 & Y1.5 & 0,741 & Valid \\
\hline 23 & Y1.6 & 0,843 & Valid \\
\hline 24 & Y1.7 & 0,799 & Valid \\
\hline 25 & Y1.8 & 0,825 & Valid \\
\hline 26 & Y1.9 & 0,772 & Valid \\
\hline 27 & Y1.10 & 0,823 & Valid \\
\hline 28 & Y1.11 & 0,807 & Valid \\
\hline 29 & Y1.12 & 0,781 & Valid \\
\hline 30 & Y1.13 & 0,747 & Valid \\
\hline 31 & Y2.1 & 0,910 & Valid \\
\hline 32 & Y 2.2 & 0,824 & Valid \\
\hline 33 & Y 2.3 & 0,892 & Valid \\
\hline 34 & Y2.4 & 0,912 & Valid \\
\hline
\end{tabular}

Sumber: data diolah (2017)

\section{Uji Reliabilitas}

Pada uji reliabilitas yang dilakukan terhadap setiap variabel penelitian memperoleh hasil bahwa nilai Cronbach's Alpha pada tiap variabel penelitian ini menunjukkan nilai yang lebih besar dari 0,6 . Hal tersebut menunjukkan bahwa semua variabel penelitian ini reliabel sehingga dapat digunakan untuk melakukan penelitian. 
Tabel 2 Uji Reliabilitas Variabel Penelitian

\begin{tabular}{clcc}
\hline No & \multicolumn{1}{c}{ Variabel } & Koefisien Korelasi & Keterangan \\
\hline 1 & Kepuasan Konsumen & 0,969 & Reliabel \\
2 & Word of Mouth & 0,947 & Reliabel \\
3 & Loyalitas Konsumen & 0,907 & Reliabel \\
\hline
\end{tabular}

Sumber: data diolah (2017)

\section{Analisis Jalur}

Analisis ini dilakukan dengan tahapan sebagai berikut.

1) Merancang model berdasarkan teori

Model tersebut juga dapat dinyatakan dalam bentuk persamaan, sehingga membentuk sistem persamaan berikut.

$$
\begin{array}{ll}
\mathrm{Y}_{1}=\beta_{1} \mathrm{X}+\mathrm{e} & (\text { Model } 1) \\
\mathrm{Y}_{2}=\beta_{1} \mathrm{X}+\beta_{2} \mathrm{Y}_{1}+\mathrm{e} & (\text { Model } 2)
\end{array}
$$

2) Memeriksa asumsi dalam jalur

Untuk pemeriksaan terhadap asumsi ini, dapat dilakukan dengan melihat susunan model teoritis yang telah dibangun dengan memperlihatkan bentuk hubungan antar variabel adalah linier.

3) Pendugaan parameter atau perhitungan koefisien path

Untuk pendugaan parameter dilakukan dengan analisis regresi melalui SPSS 22.0 diperoleh hasil sebagai berikut.

Substruktur 1:

$\mathrm{Y}_{1}=\beta_{1} \mathrm{X}_{1}+\mathrm{e}$

Dari hasil perhitungan pada pengujian data diperoleh hasil sebagai berikut. 
Tabel 3. Coefficients Substruktur 1 (Model 1)

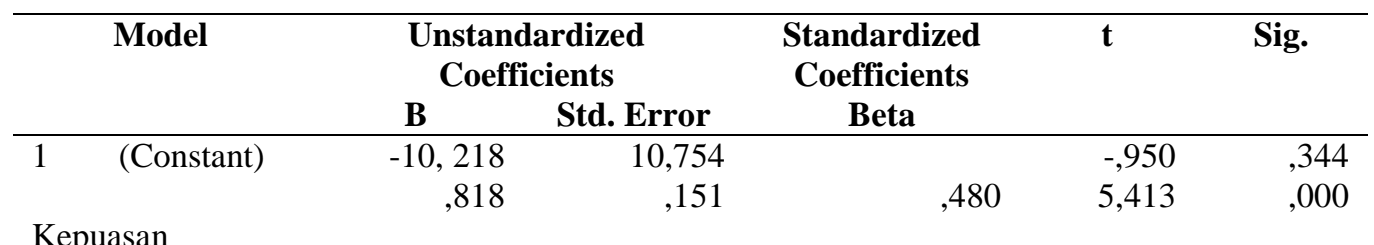

a. Dependent Variable : WOM

Sumber: data diolah (2017)

Substruktur 2:

$\mathrm{Y}_{2}=\beta_{1} \mathrm{X}+\beta_{2} \mathrm{Y}_{1}+\mathrm{e}$

Tabel 4. Coefficients Substruktur 2 (Model 2)

\begin{tabular}{|c|c|c|c|c|c|}
\hline \multirow[t]{2}{*}{ Model } & \multicolumn{2}{|c|}{$\begin{array}{l}\text { Unstandardized } \\
\text { Coefficients }\end{array}$} & \multirow{2}{*}{$\begin{array}{c}\text { Standardized } \\
\text { Coefficients } \\
\text { Beta }\end{array}$} & \multirow[t]{2}{*}{$\mathbf{t}$} & \multirow[t]{2}{*}{ Sig. } \\
\hline & B & Std. Error & & & \\
\hline $\begin{array}{l}1 \\
\text { (Constant) }\end{array}$ & $-1,463$ & ,692 & & $-2,114$ & ,037 \\
\hline Kepuasan & ,154 & ,011 & ,360 & 13,997 & ,000 \\
\hline WOM & , 188 & ,006 & ,769 & 29,111 &, 000 \\
\hline
\end{tabular}

a. Dependent Variable : Loyalitas

Sumber: data diolah (2017)

Tabel 5. Pengaruh Langsung, Pengaruh Tidak Langsung, Pengaruh Total

\begin{tabular}{|c|c|c|c|c|c|}
\hline \multicolumn{3}{|c|}{ Variabel } & $\begin{array}{l}\text { Pengaruh } \\
\text { Langsung }\end{array}$ & $\begin{array}{l}\text { Pengaruh } \\
\text { tidak langsung } \\
\text { melalui word of } \\
\text { mouth (WOM) }\end{array}$ & $\begin{array}{c}\text { Pengaruh } \\
\text { Total }\end{array}$ \\
\hline Kepuasan & & Word of Mouth & & & \\
\hline Konsumen & $\rightarrow$ & $(\mathrm{WOM})$ & 0,480 & - & 0,480 \\
\hline Kepuasan & & Loyalitas & & & \\
\hline Konsumen & $\rightarrow$ & Konsumen & 0,360 & 0,369 & 0,729 \\
\hline Word of Mouth & & Loyalitas & & & \\
\hline$(\mathrm{WOM})$ & $\rightarrow$ & Konsumen & 0,769 & - & 0,769 \\
\hline
\end{tabular}

Sumber : data diolah (2017)

4) Pemeriksaan validasi model.

Hasil koefisien determinasi $\mathrm{R}_{\mathrm{m}}{ }_{\mathrm{m}}=1-(1-0,230)(1-0,951)$ 
$\mathrm{R}_{\mathrm{m}}^{2}=1-0,107$

$\mathrm{R}_{\mathrm{m}}{ }=0,96$

Artinya, keragaman data yang dapat dijelaskan oleh model adalah sebesar 96,1 persen atau dengan kata lain informasi yang terkandung dalam data sebesar 96,1 persen dapat dijelaskan oleh model, sedangkan sisanya yaitu 3,9 persen dijelaskan oleh variabel lain (tidak terdapat dalam model) dan error.

\section{Interpretasi Model}

1. Pengaruh Kepuasan Konsumen terhadap Word of Mouth(WOM) pada Green Product Merek Oriflame

Hipotesis yang digunakan adalah sebagai berikut :

H1: Kepuasan konsumen berpengaruh signifikan terhadap word of mouth (WOM) pada green product merek Oriflame.

Dengan kriteria uji sebagai berikut:

Jika sig $\mathrm{t}<0,05$, maka $\mathrm{H}_{0}$ ditolak dan $\mathrm{H}_{1}$ diterima.

Jika sig $\mathrm{t}>0,05$, maka $\mathrm{H}_{1}$ ditolak dan $\mathrm{H}_{0}$ diterima.

Berdasarkan hasil perhitungan diperoleh taraf signifikansi penelitian untuk variabel kepuasan konsumen terhadap word of mouthsebesar $0,000<0,05$, sehingga $\mathrm{H}_{0}$ ditolak dan $\mathrm{H}_{1}$ diterima, dengan kata lain kepuasan berpengaruh signifikan terhadap word of mouth pada green product merek Oriflame. Word of Mouth (WOM) menjadi salah satu bagian strategi yang dimiliki perusahaan dalam memenangkan konsumen serta menghubungkan perusahaan dengan 
konsumen. Perusahaan berharap bahwa kepuasan konsumen menciptakan perilaku konsumen yang dapat membantu perusahaan untuk menciptakan komunikasi yang lebih efektif, salah satunya adalah melalui Word of Mouth (WOM). Konsumen green product merek Oriflame, berdasarkan penelitian telah menyatakan bahwa mereka puas terhadap produk yang ditunjukkan dari kesesuaian kinerja produk dengan harapan konsumen tersebut. Dimana semakin tinggi tingkat kepuasan yang dirasakan konsumen green product merek Oriflame maka konsumen akan melakukan Word of Mouth kepada keluarga dan rekan - rekannya dengan cara selalu membicarakan hal positif mengenai produk, memberikan dorongan serta rekomendasi penggunaan produk kepada orang lain.

2. Pengaruh Word of Mouth (WOM) terhadap Loyalitas Konsumen pada Green Product Merek Oriflame

Hipotesis yang digunakan adalah sebagai berikut :

\section{H2: Word of Mouth (WOM) berpengaruh signifikan terhadap loyalitas konsumen pada Green Product merek Oriflame.}

Dengan kriteria uji sebagai berikut:

Jika sig $\mathrm{t}<0,05$, maka $\mathrm{H}_{0}$ ditolak dan $\mathrm{H}_{2}$ diterima.

Jika sig $\mathrm{t}>0,05$, maka $\mathrm{H}_{2}$ ditolak dan $\mathrm{H}_{0}$ diterima.

Berdasarkan hasil perhitungan diperoleh taraf signifikansi penelitian untuk variabel word of mouth (WOM) terhadap loyalitas konsumensebesar 0,000< 0,05, sehingga $\mathrm{H}_{0}$ ditolak dan $\mathrm{H}_{2}$ diterima, dengan kata lain word of mouth (WOM) berpengaruh signifikan terhadap loyalitas konsumen pada green 
product merek Oriflame. Hasil penelitian menunjukkan bahwa konsumen green product merek Oriflame memiliki kemauan untuk membicarakan hal hal yang positif berkaitan dengan produk, konsumen bahkan mau untuk mendorong dan merekomendasikan penggunaan produk kepada orang lain baik teman maupun keluarganya. Word of Mouth (WOM) yang positif tersebut mendorong terbentuknya loyalitas konsumen yang ditandai dengan penggunaan produk secara kontinu (berulang - ulang kali) dan keengganan untuk beralih ke merek produk lainnya.

3. Pengaruh Kepuasan terhadap Loyalitas Konsumen pada Green Product Merek Oriflame

Hipotesis yang digunakan adalah sebagai berikut :

\section{H3: Kepuasan konsumen berpengaruh signifikan terhadap loyalitas konsumen pada Green Product merek Oriflame}

Dengan kriteria uji sebagai berikut:

Jika sig $\mathrm{t}<0,05$, maka $\mathrm{H}_{0}$ ditolak dan $\mathrm{H}_{3}$ diterima.

Jika sig $\mathrm{t}>0,05$, maka $\mathrm{H}_{3}$ ditolak dan $\mathrm{H}_{0}$ diterima.

Berdasarkan hasil perhitungan diperoleh taraf signifikansi penelitian untuk variabel kepuasan konsumen terhadap loyalitas konsumensebesar 0,000< 0,05, sehingga $\mathrm{H}_{0}$ ditolak dan $\mathrm{H}_{3}$ diterima, dengan kata lain kepuasan konsumen berpengaruh signifikan terhadap loyalitas konsumen pada green product merek Oriflame. Berdasarkan hasil penelitian, diperoleh bahwa konsumen merasa puas dengan green product merek Oriflame baik itu puas terhadap kualitas dan manfaat produk, harga produk yang sesuai dengan 
harapan konsumen, kelengkapan dan pendistribusian produk yang baik, proses pemesanan produk yang cepat, adanya program - program promosi yang menarik, layanan keluhan pelanggan yang selalu sigap, dan kinerja konsultan produk yang prima telah sesuai dengan harapan konsumen. Kepuasan ini dapat ditingkatkan dengan selalu berkomitmen pada kualitas produk dan layanan yang unggul, sehingga pada akhirnya bermuara pada loyalitas konsumen pada produk kosmetik dan perawatan tubuh merek Oriflame. Apabila konsumen atau pelanggan telah puas terhadap kinerja suatu perusahaan atau produk, maka kepuasan konsumen inilah yang menjadi dasar menuju terwujudnya konsumen yang loyal atau setia. Dengan demikian kunci keberhasilan perusahaan sebenarnya sangat tergantung kepada suksesnya perusahaan dalam memuaskan konsumen.

4. Pengaruh Kepuasan Konsumen terhadap Loyalitas Konsumen Melalui Mediasi Word of Mouth (WOM) pada Green Product Merek Oriflame.

Hipotesis yang digunakan adalah sebagai berikut.

\section{H4: Word of Mouth Memediasi Pengaruh Kepuasan Konsumen terhadap Loyalitas Konsumen pada Green Product Merek Oriflame}

Dengan kriteria uji sebagai berikut:

Jika $\mathrm{Z}_{\text {hitung }}>\mathrm{Z}_{\text {tabel, }}$, maka $\mathrm{H}_{0}$ ditolak dan $\mathrm{H}_{1}$ diterima.

Berdasarkan hasil perhitungan diperoleh $\mathrm{Z}_{\text {hitung }}(5,04)>\mathrm{Z}_{\text {tabel }}(1,96)$, sehingga $\mathrm{H}_{0}$ ditolak dan $\mathrm{H}_{4}$ diterima, dengan kata lain word of mouth (WOM) mampu 
memediasi pengaruh kepuasan konsumen dengan loyalitas konsumen. Konsumen yang loyal terbentuk dari konsumen yang terpuaskan nilai pribadinya dan mengalami pengalaman yang positif dalam menggunakan produk maka kemudian akan memiliki loyalitas yang tinggi terhadap perusahaan tersebut. Konsumen yang terpuaskan akan melakukan komunikasi yang efektif dengan membicarakan hal - hal positif dengan orang lain termasuk teman dan kerabat mereka. Selanjutkan hal tersebut akan mendorong terbentuknya loyalitas konsumen. Konsumen yang loyal akan memiliki komitmen untuk bertahan secara mendalam dalam berlangganan kembali atau melakukan pembelian ulang produk atau jasa terpilih secara konsisten dimasa yang akan datang, meskipun pengaruh situasi dan usaha-usaha pemasaran mempunyai potensi untuk menyebabkan perubahan perilaku.

\section{SIMPULAN}

Berdasarkan hasil dan pembahasan penelitian dapat ditarik simpulan sebagai berikut:

1. Kepuasan konsumen berpengaruh signifikan terhadap word of mouth (WOM) pada green product merek Oriflame.

2. Word of mouth (WOM) berpengaruh signifikan terhadap loyalitas konsumen pada green product merek Oriflame.

3. Kepuasan konsumen berpengaruh signifikan terhadap loyalitas konsumen pada green product merek Oriflame.

4. Word of Mouth (WOM) berperan memediasi pengaruh kepuasan terhadap loyalitas konsumen pada green product merek Oriflame. 
Saran - saran yang dapat dikemukakan dalam penelitian ini, yaitu:

1. Perusahaan perlu menjaga konsistensi dan komitmen dalam memproduksi produk kosmetika merek Oriflame yang mengedepankan produk berbasis lingkungan untuk memberikan pengaruh pada kepuasan konsumen. Berdasarkan hasil penelitian, konsumen memberikan pernyataan kepuasan pada kualitas dan manfaat produk, reward dan program promosi, termasuk kepuasan dari pelayanan kantor pemasaran hingga ke proses pemesanan dan distribusi produk. Disamping itu, dengan mengembangkan produk berbahan dasar alami, konsumen mendapatkan rasa aman dan percaya bahwa produk kosmetik tersebut tidak menimbulkan efek samping jika dipergunakan sehari - hari.

2. Membentuk citra sebagai produsen produk hijau atau ramah lingkungan tidak hanya ditunjukkan melalui kampanye pemasaran di berbagai media promosi saja, tetapi juga ditunjukkan dengan komitmen untuk terus - menerus melakukan pengembangan dan inovasi produk yang aman dan berbahan dasar alami sehingga tidak berbahaya bagi kulit dan tubuh. Berdasarkan hasil penelitian, ditemukan bahwa konsumen Oriflame di Kota Denpasar telah merasakan kepuasan terhadap green product merek Oriflame tersebut, sehingga dengan kepuasan ini perusahaan dapat mendorong komunikasi yang efektif dari konsumen melalui word of mouth. Kampanye iklan yang semakin gencar ditambah lagi dengan reward atau program promosi yang menguntungkan akan membuat konsumen terus - menerus membicarakan hal - hal positif tentang produk. Komunikasi dari konsumen ke konsumen lainnya merupakan bentuk promosi yang "gratis", dimana dapat menjadi salah satu strategi yang efektif untuk meningkatkan loyalitas konsumen yang ditunjukkan dari pembelian ulang produk secara rutin dan teratur, keengganan untuk beralih ke merek lain, bahkan merekomendasikan penggunaan produk tanpa diminta ke orang lain/konsumen lainnya. Hal inilah yang dapat menjadi keunggulan kompetitif bagi perusahaan Oriflame itu sendiri untuk memenangkan persaingan dalam industri kosmetik dewasa ini. 
3. Bagi peneliti selanjutnya diharapkan mampu mengembangkan model penelitian ini dengan menambahkan variabel lain yang mempengaruhi WOM seperti kualitas pelayanan dan brand image yang didukung dengan teori dan isu - isu terbaru. Peneliti selanjutnya juga diharapkan untuk memperluas ruang lingkup wilayah penelitian dan lokasi penelitian sehingga hasil penelitian dapat diimplementasikan secara lebih luas.

\section{DAFTAR PUSTAKA}

Balawera, Asrianto. 2013. Green Marketing dan Corporate Social Responsibility Pengaruhnya Terhadap Keputusan Pembelian Konsumen Melalui Minat Membeli Produk Organik di Fresh Mart Kota Manado. Jurnal EMBA 1 (4).

Chang, N.J and C.M.Fong. 2010. "Green Product Quality, Green Corporate Image, Green Constomer Satisfaction, and Green Customer Loyalty". African Journal of Business Management. 4(14), 2836-44

Chen, Y.S.2010. "The Driver of Green Innovation and Green Image - Green Core Competence". Journal of Business Ethics. 81(3), 531-543

Gaffar, Vanessa. 2007. CRM dan MPR Hotel. Bandung: CV. Alfabeta

Griffin, Jill. 2005. Customer Loyalty: Menumbuhkan dan Mempertahankan Kesetiaan Pelanggan. Edisi Revisi dan Terbaru. Jakarta: PT. Erlangga

Ghozali, Imam. 2001. Aplikasi Analisis Multivariate Dengan Program SPSS. Semarang: Badan Penerbit Universitas Diponegoro

Hayu, Suthia Rina. 2014. The Influence of Satisfaction, Trust, And Price of Consumer Loyalty on Green Product (Case in Kandang Village Society of Bengkulu City, Which Have Been Using Enegy Saving Lighting Product). E-Journal Management Insight, 9(1), 30 - 44

Kotler dan Keller, K.L. 2009. Manajemen Pemasaran, Jilid 1. Edisi Kedua Belas. Alih Bahasa : Benyamin Molan. Jakarta: PT. Indeks

Khoiriyah, Siti dan Suam Toro, Muh Juan. 2014. Faktor - Faktor yang Mempengaruhi Kesediaan Membeli Produk Hijau. Jurnal Bisnis \& Manajemen. Vol. 14 (1): 63 - 76

Sutisna dan Pawitra. 2001. Perilaku Konsumen dan Komunikasi Pemasaran. Bandung: PT.Remaja Rosdakarya

Riduwan. 2014. Path Analysis. Bandung: CV Alfabeta

Susanti, Hani Ni Putu dan Wardana, I Made. 2015. Pengaruh Kualitas Produk dan Citra Merek Terhadap Kepuasan dan Loyalitas Pelanggan Pada Produk Kosmetik Hijau Merek The Body Shop. E-Journal Manajemen Universitas Udayana, 4(5), 622 - 636

Schiffman dan Kanuk. 2010. Perilaku Konsumen. Jakarta: PT. Indeks

Tjiptono, Fandy. 2007. Strategi Pemasaran, Edisi Kedua. Yogyakarta: Penerbit Andi 